\title{
CT-Based Measurements of Facial Parameters of Healthy Children and Adolescents in Thailand
}

\author{
(D) N. Jullabussapa, (D). Khwanngern, (D) C. Pateekhum, (D) C. Angkurawaranon, and (D). Angkurawaranon
}

\begin{abstract}
BACKGROUND AND PURPOSE: Facial parameters are used for evaluating normal growth patterns, diagnosing patients with craniofacial abnormalities, and planning surgical procedures. However, these parameters vary by ethnicity and race. This study aims to describe soft-tissue and bony facial parameters based on CT of healthy pediatric and adolescent patients in Thailand.
\end{abstract}

MATERIALS AND METHODS: CT imaging of the brain, orbit, facial bones, and neck was performed at Maharaj Nakorn Chiangmai Hospital, in patients from birth to 19 years old. Patients with known syndromic disease, craniofacial syndrome, facial trauma and/or infection, and previous surgery that deformed the study area were excluded. The key points of measurement were soft-tissue intercanthal, bony interorbital, and bony lateral orbital distances.

RESULTS: There were 932 patients: 554 males (59.4\%) and 378 females (40.6\%). Facial parameters rapidly increased in the first 2 years of life. Significant differences in these parameters between the males and females were found at the age of $\geq 15$ years. However, ratios of the interorbital to the lateral orbital distance were generally consistent among age groups in both sexes, at 0.25 .

CONCLUSIONS: This study, in Thailand, provides detailed age- and sex-specific normative data of the craniofacial measurements in children and adolescences based on CT imaging. These data can be used for evaluating individual patients with craniofacial abnormalities as well as determining the treatment in Thai and Asian populations, in whom craniofacial abnormalities, for example, frontoethmoidal encephalomeningocele, are common.

ABBREVIATIONS: IC = intercanthal; IO = interorbital; $L O=$ lateral orbital; SD = standard deviation

$\mathbf{F}$ acial parameters and proportions play important roles in medicine because they are used for evaluating normal growth patterns, diagnosing patients with craniofacial abnormalities, and planning surgical procedures. ${ }^{1,2}$ One of the most common craniofacial abnormalities in southeast Asia is frontoethmoidal encephalomeningocele, ${ }^{3}$ a congenital pediatric disorder characterized by herniation of the brain and the meninges through an anterior skull defect that usually involves the orbits. ${ }^{3-5}$ Although rare in Europe and the United States, it has been described in several pediatric groups of different races in southeast Asia, including Thais, Malaysians, and Burmese. ${ }^{3}$ The incidence of frontoethmoidal

Received March 17, 2020; accepted after revision June 23.

From the Department of Radiology (N.J., S.A.); Division of Plastic Surgery (K.K.), Department of Surgery; Department of Family Medicine (C.P., C.A.), Faculty of Medicine, Chiang Mai University, Sriphum, Muang, Chiang Mai, Thailand.

Please address correspondence to Salita Angkurawaranon, MD, Department of Radiology, Faculty of Medicine, Chiang Mai University, 110 Intawaroros Rd, Sriphum, Muang, Chiang Mai, Thailand 50200; e-mail: salita.ang@cmu.ac.th

- Indicates open access to non-subscribers at www.ajnr.org

Indicates article with supplemental on-line photos.

http://dx.doi.org/10.3174/ajnr.A6731 encephalomeningocele in Thailand and Burma is 1:5000 to 1:6000 live births. ${ }^{6}$ Treatment for frontoethmoidal encephalomeningocele includes surgery, which requires normal facial parameters for orbital reconstruction.

Existing data of the facial parameters have been collected by using one or more of these methods: direct measurement (anthropometric), radiographic measurement (cephalometric), and sonography measurement of the fetus in utero. ${ }^{7}$ Each method has its own limitations in accurately measuring normative standards for craniofacial measurements. Most of the data were collected and applied to adult populations. ${ }^{1,2,8-11}$ Available data for the pediatric population is reported to a much lesser extent. ${ }^{11-13} \mathrm{CT}$ is now considered as the main technique for diagnosis, follow-up, and surgical planning for reconstructive surgery. There is literature that indicates that CT is more accurate and reliable than other cephalometric measures. ${ }^{14}$ Furthermore, CT measurements are reliable and reproducible; results of studies have suggested that the accuracy, interobserver error, and intraobserver error are often within an acceptable range (within $1 \mathrm{~mm}$ ) for craniofacial measurements. ${ }^{15,16}$

Facial characteristics vary across multiple ethnicities. ${ }^{1,2,8,17,18}$ There are limited normative craniofacial parameters based on CT 


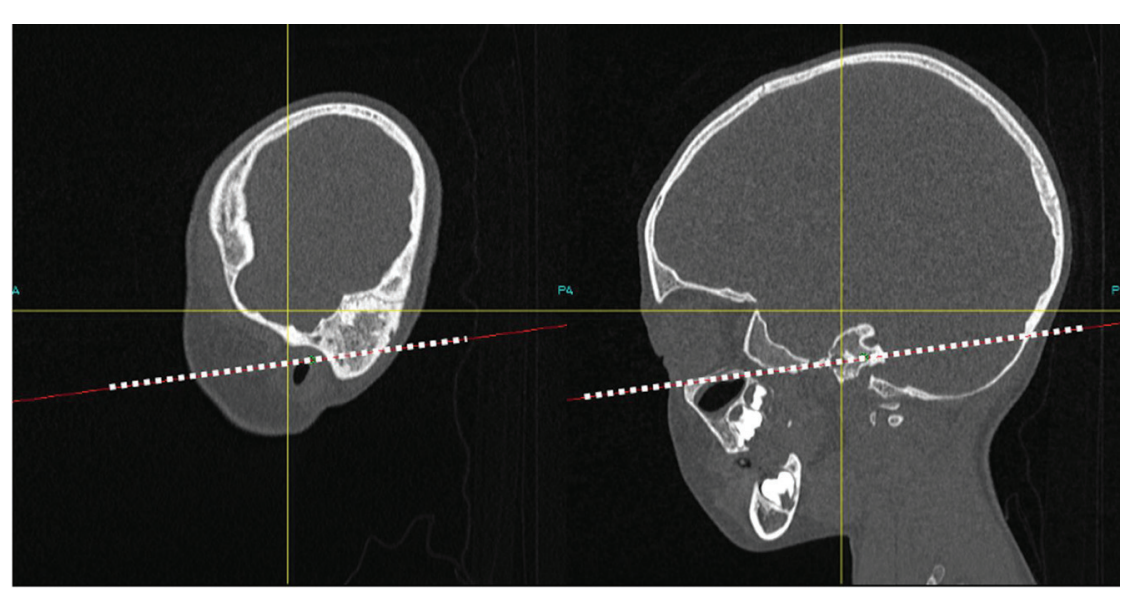

FIG 1. Multiplanar reconstruction CT of the facial bone in the sagittal view. The dotted line represents the Frankfort horizontal plane.
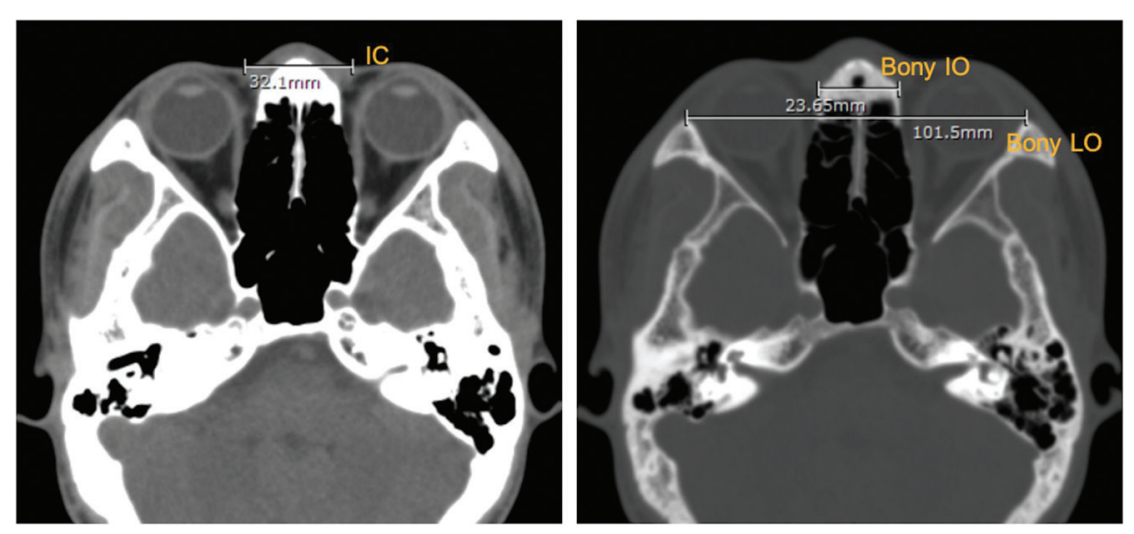

FIG 2. An axial CT of the brain. Left, soft-tissue intercanthal (IC); right, bony interorbital (IO) and bony lateral orbital (LO) distances, which measure 32.10, 23.65, and $101.50 \mathrm{~mm}$, respectively.

and 2016, in patients from birth to 19 years old was retrospectively reviewed. Maharaj Nakorn Chiang Mai Hospital is a tertiary university hospital that acts as a referral center for northern Thailand. Based on the patient's history review and evaluation of imaging, we excluded any patient with a known syndromic disease, craniofacial syndrome, facial trauma and/or infection, and previous surgery that deformed the study area.

All the scans were produced by using 2 multidetector CT machines: 1) Dual sources Somatom Force (Siemens), and 2) Dual sources Somatom Definition, (Siemens). The CT images were reviewed in soft-tissue and bone windows. The 4 key points measured were intercanthal (IC), bony interorbital (IO), bony lateral orbital (LO) distances, and the IO:LO ratio. These points of measurement, determined by the craniofacial surgeon (K.K.) and the radiologists (N.J., S.A.), were considered to be useful for clinical purposes and reproducibility. These points of measure were also those suggested by a previous study from Thailand. $^{20}$ All measurements were performed by research assistants who were trained by a board-certificated diagnostic neuroradiologist (S.A.) by using the PACS.

Orientation was in the Frankfort

among populations in Asian countries, for example, Thailand. One study was conducted in India and used CT from 100 adults, ${ }^{19}$ and one study was from Thailand and used CT from 349 patients (ages, 0-21 years), with a broad categorization of age groups into 2to 3 -year age bands with both sexes grouped together. ${ }^{20}$ These limited data with relatively small sample sizes make the establishment of normative data difficult because the facial parameters may change rapidly in early life due to cranial growth. The cranium triples in size during the first year of life, is $75 \%$ complete at age 2 years, and is $95 \%$ complete by age 10 years. Some biologic variation between the sexes also exists because additional growth thereafter is usually complete by ages 16-18 years in girls and 18-20 years in boys. Thus, more-detailed normative data are needed to document normal growth patterns. This will be useful for monitoring and diagnosing those suspected with craniofacial anomalies, such as telecanthus, pseudohypertelorism, or ocular hypertelorism as well as for pediatric patients with frontoethmoidal encephalomeningocele who require surgical reconstruction.

\section{MATERIALS AND METHODS}

All CT imaging of the brain, orbit, facial bone, and neck performed at Maharaj Nakorn Chiang Mai Hospital between 2013 horizontal plane, defined as the highest point on the upper margin of the opening of the external auditory canal and the lowest point on the lower margin of the orbit (Fig 1). After the Frankfort horizontal plane was identified, the measurements of the soft-tissue IC, bony IO, and bony LO distances in millimeters (Fig 2) were performed. The IC distance was defined as the distance between medial canthi. IO and LO distances were defined as the distance between the medial wall of orbits and the distance between the lateral wall of orbits, respectively. Key points of measurement were summarized by using descriptive statistics with the calculation of means and standard deviations (SDs). Data were divided by different age groups. Due to the rapid growth of the skull and face during early life, age groups were categorized by every 3 months until 2 years of age, then every year until age 19 years. Male and female patients were analyzed separately, and comparisons between the sexes within each age group were conducted by using $t$-tests.

\section{RESULTS}

A total of 983 scans from 932 individuals were reviewed, of whom 554 were males (59.4\%) and 378 were females (40.6\%). The mean \pm SD age for males was $9.0 \pm 6.5$ years and for females 
Table 1: Values for soft-tissue intercanthal distances by age group and sex

IC Distance, Mean \pm Standard

Deviation, $\mathrm{mm}$

\begin{tabular}{lrccc}
\cline { 2 - 5 } Age Group & \multicolumn{1}{c}{ All } & Males & Females & $\boldsymbol{P}$ \\
\hline 0-3 months $(n=76)$ & $22.1 \pm 2.8$ & $22.6 \pm 2.7$ & $21.3 \pm 2.7$ & .05 \\
$>3-6$ months $(n=41)$ & $23.9 \pm 2.7$ & $24.5 \pm 2.9$ & $23.3 \pm 2.4$ & .15 \\
$>6-9$ months $(n=40)$ & $24.1 \pm 2.5$ & $24.8 \pm 2.2$ & $23.7 \pm 2.7$ & .17 \\
$>9-12$ months $(n=30)$ & $24.3 \pm 2.1$ & $24.0 \pm 2.1$ & $24.8 \pm 2.1$ & .34 \\
$>12-15$ months $(n=25)$ & $26.1 \pm 3.3$ & $26.3 \pm 3.9$ & $25.9 \pm 2.3$ & .75 \\
$>15-18$ months $(n=14)$ & $25.6 \pm 3.3$ & $24.8 \pm 2.1$ & $26.3 \pm 4.0$ & .42 \\
$>18-21$ months $(n=21)$ & $26.4 \pm 3.4$ & $26.5 \pm 3.6$ & $26.4 \pm 3.3$ & .95 \\
$>21-24$ months $(n=12)$ & $27.3 \pm 3.8$ & $26.2 \pm 3.8$ & $28.7 \pm 3.8$ & .29 \\
$>2-3$ years $(n=49)$ & $27.1 \pm 3.3$ & $27.8 \pm 3.1$ & $26.1 \pm 3.2$ & .08 \\
$>3-4$ years $(n=36)$ & $27.8 \pm 3.3$ & $28.3 \pm 2.5$ & $27.1 \pm 3.0$ & .26 \\
$>4-5$ years $(n=42)$ & $28.0 \pm 2.8$ & $27.4 \pm 3.0$ & $28.9 \pm 2.3$ & .08 \\
$>5-6$ years $(n=41)$ & $27.7 \pm 2.9$ & $28.2 \pm 3.0$ & $27.0 \pm 2.7$ & .21 \\
$>6-7$ years $(n=36)$ & $29.3 \pm 3.4$ & $30.1 \pm 3.9$ & $28.7 \pm 2.8$ & .20 \\
$>7-8$ years $(n=29)$ & $29.2 \pm 3.8$ & $28.7 \pm 3.4$ & $30.1 \pm 4.5$ & .37 \\
$>8-9$ years $(n=26)$ & $29.3 \pm 2.6$ & $29.4 \pm 2.7$ & $29.1 \pm 2.6$ & .71 \\
$>9-10$ years $(n=30)$ & $30.7 \pm 3.3$ & $31.4 \pm 3.8$ & $30.0 \pm 2.3$ & .19 \\
$>10-11$ years $(n=31)$ & $29.5 \pm 3.6$ & $29.0 \pm 2.7$ & $30.3 \pm 4.5$ & .31 \\
$>11-12$ years $(n=33)$ & $30.2 \pm 3.9$ & $30.3 \pm 4.6$ & $30.0 \pm 2.0$ & .80 \\
$>12-13$ years $(n=32)$ & $31.1 \pm 3.2$ & $31.8 \pm 3.1$ & $29.2 \pm 2.7$ & .03 \\
$>13-14$ years $(n=42)$ & $31.4 \pm 4.4$ & $30.9 \pm 3.7$ & $31.9 \pm 5.2$ & .50 \\
$>14-15$ years $(n=43)$ & $31.5 \pm 3.9$ & $31.6 \pm 3.4$ & $31.1 \pm 5.0$ & .68 \\
$>15-16$ years $(n=69)$ & $32.9 \pm 4.6$ & $33.9 \pm 4.6$ & $31.8 \pm 4.3$ & .05 \\
$>16-17$ years $(n=71)$ & $32.8 \pm 3.9$ & $32.9 \pm 4.0$ & $32.8 \pm 3.5$ & .91 \\
$>17-18$ years $(n=57)$ & $32.7 \pm 3.9$ & $33.6 \pm 3.8$ & $30.4 \pm 3.2$ & $<.01$ \\
$>18-19$ years $(n=57)$ & $32.7 \pm 4.2$ & $34.2 \pm 4.1$ & $30.2 \pm 2.7$ & $<.01$ \\
\hline & & & &
\end{tabular}

Table 2: Values for bony interorbital distances by age group and sex

\begin{tabular}{lcccc}
\hline & \multicolumn{3}{c}{ IO Distance, Mean \pm Standard } \\
Age Group (No. Scans & \multicolumn{3}{c}{ Deviation, mm } & \\
\cline { 2 - 4 } Per Group) & All & Males & Females & $P$ \\
\hline 0-3 months (76) & $16.4 \pm 1.9$ & $16.5 \pm 2.1$ & $16.1 \pm 1.8$ & .39 \\
$>3-6$ months (41) & $18.2 \pm 2.0$ & $18.4 \pm 2.6$ & $18.0 \pm 1.3$ & .57 \\
$>6-9$ months (40) & $17.7 \pm 2.1$ & $19.5 \pm 2.4$ & $17.2 \pm 1.8$ & .07 \\
$>$ >-12 months (30) & $18.1 \pm 2.0$ & $18.1 \pm 1.6$ & $17.9 \pm 2.6$ & .79 \\
$>12-15$ months (25) & $18.8 \pm 2.2$ & $18.9 \pm 2.0$ & $18.5 \pm 2.5$ & .66 \\
$>15-18$ months (14) & $18.5 \pm 2.3$ & $18.2 \pm 1.6$ & $18.7 \pm 2.7$ & .67 \\
$>18-21$ months (21) & $19.1 \pm 2.8$ & $19.2 \pm 2.0$ & $19.0 \pm 3.7$ & .90 \\
$>21-24$ months (12) & $18.6 \pm 1.4$ & $19.1 \pm 1.6$ & $18.1 \pm 1.7$ & .22 \\
$>2-3$ years (49) & $19.3 \pm 2.1$ & $20.0 \pm 2.0$ & $18.3 \pm 1.8$ & $<.01$ \\
$>3-4$ years (36) & $19.8 \pm 2.3$ & $19.8 \pm 2.4$ & $19.8 \pm 2.3$ & .94 \\
$>4-5$ years (42) & $20.4 \pm 2.6$ & $20.1 \pm 2.0$ & $20.8 \pm 3.3$ & .37 \\
$>5-6$ years (41) & $20.5 \pm 2.4$ & $20.7 \pm 2.3$ & $20.3 \pm 2.7$ & .69 \\
$>6-7$ years (36) & $22.3 \pm 2.4$ & $22.9 \pm 2.8$ & $21.9 \pm 2.0$ & .25 \\
$>7-8$ years (29) & $22.5 \pm 3.0$ & $22.2 \pm 2.8$ & $21.1 \pm 3.3$ & .43 \\
$>8-9$ years (26) & $22.2 \pm 2.1$ & $22.8 \pm 2.1$ & $21.1 \pm 1.7$ & .04 \\
$>9-10$ years (30) & $23.1 \pm 2.5$ & $24.1 \pm 2.1$ & $21.7 \pm 2.3$ & $<.01$ \\
$>10-11$ years (31) & $23.1 \pm 2.0$ & $22.9 \pm 2.4$ & $23.3 \pm 1.2$ & .66 \\
$>11-12$ years (33) & $22.8 \pm 2.3$ & $23.0 \pm 2.7$ & $22.4 \pm 1.6$ & .48 \\
$>12-13$ years (32) & $24.3 \pm 3.5$ & $24.6 \pm 3.6$ & $23.6 \pm 3.7$ & .49 \\
$>13-14$ years (42) & $24.2 \pm 3.3$ & $23.9 \pm 3.1$ & $24.4 \pm 3.5$ & .64 \\
$>14-15$ years (43) & $24.6 \pm 3.1$ & $24.8 \pm 3.2$ & $24.1 \pm 2.8$ & .48 \\
$>15-16$ years (69) & $24.6 \pm 3.0$ & $25.4 \pm 3.3$ & $23.7 \pm 2.5$ & .02 \\
$>16-17$ years (71) & $25.3 \pm 3.1$ & $25.6 \pm 3.0$ & $24.4 \pm 3.3$ & .13 \\
$>17-18$ years (57) & $24.7 \pm 2.9$ & $25.3 \pm 2.6$ & $23.2 \pm 3.2$ & .01 \\
$>18-19$ years (57) & $24.8 \pm 2.6$ & $25.7 \pm 2.2$ & $23.4 \pm 2.7$ & $<.01$ \\
\hline & & & &
\end{tabular}

was $7.8 \pm 6.4$ years. The mean measurements of soft tissue IC, bony IO, and bony LO distances for both sexes, categorized by age group, are shown in Tables 1-3. As expected, there was a rapid increase in the IC distance in the first 2 years of life. The average \pm SD IC distance was $22.1 \pm 2.8 \mathrm{~mm}$ among neonates ( $0-3$ months). At $22-24$ months, the average \pm SD IC distance was $27.3 \pm 3.8 \mathrm{~mm}$ or approximately $80 \%$ of the mean IC distances among adults ages $>18$ years (Table 1 and On-line Fig 1 ). The average IC distances increased with age. By the age of 8 years, the mean IC distance was $29.2 \mathrm{~mm}$ or approximately $90 \%$ of the mean IC distance among adults aged $>18$ years. Small differences between the sexes, between 1 and $2 \mathrm{~mm}$, were also detected among those $>15$ years of age. On average, after the age of 15 years, males tended to have larger IC distances than did the females. By age 15 years, among the males, the average IC distance was approximately $90 \%$ of the mean IC distances among adult men at $>18$ years. For females, by age 15 years, the average IC distance was already similar to the mean IC distances among adult women at age $>18$ years (Table 1).

This pattern of rapid growth in early life and difference between males and females aged $>15$ years was also observed from IO distances and LO distances. Among neonates (ages, $0-3$ months), the average IO distance was $16.4 \mathrm{~mm}$ and was $18.6 \mathrm{~mm}$ by age 2 years. By the age of 8 years, the average IO distance as $22.5 \mathrm{~mm}$ or $90 \%$ of the mean IO distance in adulthood. Among those $>15$ years of age, the mean IO distance was 1-2 mm longer for men compared with women (Table 2 and On-line Fig 2). As demonstrated in Table 3, by 2 years of age, the average LO distance $(77.3 \mathrm{~mm})$ was also nearly $80 \%$ of the average LO distances among adults $>18$ years $(90.0 \mathrm{~mm})$. By the age of 8 years, the average LO distance $(88.1 \mathrm{~mm})$ was also almost $90 \%$ of the average adult LO distance at the age of 18 years. Similar to IC and IO distances, after the age of 15 years, the average LO size was 3-5 $\mathrm{mm}$ longer among men compared with women (On-line Fig 3). Although there is evidence for rapid growth and small differences between the sexes in IO and LO distances after the age of 15 years, the mean ratios between $\mathrm{IO} / \mathrm{LO}$ were relatively stable, at 0.25 , across age groups and between the sexes (Table 4). Ninety percent of all the scans had an IO:LO ratio between 0.22 and 0.28 (Fig 3).

\section{DISCUSSION}

This study aimed to document normative facial parameters among children, adolescents, and young adults in Thailand by using CT. Consistent patterns emerged that facial parameters were approximately $80 \%$ developed within the first 2 years of life and $90 \%$ developed by the age of 8 years. However, small differences between the sexes in distances after the age of 15 years also existed. Despite different growth rates across different ages and sexes, the ratios between IO:LO were relatively constant. 
Table 3: Values for bony lateral orbital (LO) distances by age group and sex

\begin{tabular}{lcccc}
\hline \multirow{2}{*}{$\begin{array}{c}\text { Age Group (No. Scans } \\
\text { Per Group) }\end{array}$} & \multicolumn{2}{c}{ LO Distance, Mean \pm Standard Deviation, mm } & \\
\cline { 2 - 4 } & \multicolumn{1}{c}{ All } & Males & Females & \multicolumn{1}{c}{$\boldsymbol{P}$} \\
\hline 0-3 months (76) & $63.3 \pm 4.4$ & $63.7 \pm 4.5$ & $62.5 \pm 4.2$ & .23 \\
$>3-6$ months (41) & $69.3 \pm 4.4$ & $69.6 \pm 4.8$ & $69.0 \pm 4.1$ & .67 \\
$>6-9$ months (40) & $72.6 \pm 3.5$ & $64.7 \pm 3.0$ & $71.2 \pm 3.1$ & $<.01$ \\
$>9-12$ months (30) & $73.1 \pm 3.4$ & $73.9 \pm 3.3$ & $71.9 \pm 3.2$ & .12 \\
$>12-15$ months (25) & $75.5 \pm 3.4$ & $76.1 \pm 3.3$ & $74.6 \pm 3.4$ & .30 \\
$>15-18$ months (14) & $76.1 \pm 3.9$ & $76.7 \pm 3.8$ & $75.6 \pm 4.2$ & .63 \\
$>18-21$ months (21) & $77.3 \pm 3.2$ & $78.0 \pm 3.1$ & $76.3 \pm 3.1$ & .22 \\
$>21-24$ months (12) & $77.3 \pm 2.8$ & $78.3 \pm 2.9$ & $75.7 \pm 2.1$ & .12 \\
$>2-3$ years (49) & $80.1 \pm 3.6$ & $81.8 \pm 3.0$ & $77.8 \pm 3.1$ & $<.01$ \\
$>3-4$ years (36) & $80.6 \pm 4.6$ & $81.5 \pm 4.8$ & $79.5 \pm 4.2$ & .20 \\
$>4-5$ years (42) & $82.5 \pm 3.7$ & $82.2 \pm 4.0$ & $83.0 \pm 3.4$ & .45 \\
$>5-6$ years (41) & $83.4 \pm 3.5$ & $83.9 \pm 4.0$ & $82.7 \pm 2.6$ & .31 \\
$>6-7$ years (36) & $86.5 \pm 3.7$ & $87.5 \pm 3.6$ & $85.7 \pm 3.6$ & .13 \\
$>7-8$ years (29) & $88.1 \pm 3.7$ & $88.8 \pm 3.4$ & $87.0 \pm 4.0$ & .23 \\
$>8-9$ years (26) & $88.4 \pm 3.7$ & $89.2 \pm 3.4$ & $87.1 \pm 3.9$ & .16 \\
$>9-10$ years (30) & $90.7 \pm 3.9$ & $91.7 \pm 3.3$ & $89.4 \pm 4.3$ & .11 \\
$>10-11$ years (31) & $90.4 \pm 3.6$ & $90.7 \pm 4.3$ & $90.1 \pm 2.6$ & .66 \\
$>11-12$ years (33) & $91.0 \pm 4.3$ & $91.1 \pm 4.7$ & $90.7 \pm 3.5$ & .77 \\
$>12-13$ years (32) & $83.9 \pm 5.4$ & $94.6 \pm 5.6$ & $92.3 \pm 4.7$ & .28 \\
$>13-14$ years (42) & $93.9 \pm 4.7$ & $94.0 \pm 4.4$ & $93.9 \pm 5.1$ & .97 \\
$>14-15$ years (43) & $96.3 \pm 5.0$ & $97.2 \pm 4.9$ & $94.3 \pm 4.7$ & .08 \\
$>15-16$ years (69) & $97.1 \pm 4.6$ & $99.0 \pm 4.3$ & $95.0 \pm 4.0$ & $<.01$ \\
$>16-17$ years (71) & $98.6 \pm 4.5$ & $99.5 \pm 4.7$ & $96.2 \pm 3.2$ & $<.01$ \\
$>17-18$ years (57) & $98.9 \pm 5.0$ & $100.6 \pm 3.7$ & $94.2 \pm 5.1$ & $<.01$ \\
$>18-19$ years (57) & $99.0 \pm 5.3$ & $100.8 \pm 4.9$ & $96.0 \pm 4.6$ & $<.01$ \\
\hline
\end{tabular}

Table 4: Values for bony interorbital (IO) to lateral orbital (LO) distances by age group and sex

\begin{tabular}{|c|c|c|c|c|}
\hline \multirow{2}{*}{$\begin{array}{c}\text { Age Group (No. Scans } \\
\text { Per Group) }\end{array}$} & \multicolumn{3}{|c|}{ IO to LO Distance, Mean \pm Standard Deviation, $\mathrm{mm}$} & \multirow[b]{2}{*}{$P$} \\
\hline & All & Males & Females & \\
\hline $0-3$ months (76) & $0.26 \pm 0.02$ & $0.26 \pm 0.02$ & $0.26 \pm 0.02$ & .85 \\
\hline$>3-6$ months (41) & $0.26 \pm 0.02$ & $0.26 \pm 0.02$ & $0.26 \pm 0.02$ & .79 \\
\hline$>6-9$ months (40) & $0.24 \pm 0.03$ & $0.25 \pm 0.03$ & $0.24 \pm 0.02$ & .50 \\
\hline$>9-12$ months (30) & $0.25 \pm 0.02$ & $0.25 \pm 0.02$ & $0.25 \pm 0.03$ & .76 \\
\hline$>12-15$ months (25) & $0.25 \pm 0.02$ & $0.25 \pm 0.02$ & $0.25 \pm 0.03$ & .95 \\
\hline$>15-18$ months (14) & $0.24 \pm 0.02$ & $0.24 \pm 0.02$ & $0.25 \pm 0.02$ & .45 \\
\hline$>18-21$ months (21) & $0.25 \pm 0.03$ & $0.24 \pm 0.02$ & $0.25 \pm 0.04$ & .82 \\
\hline$>21-24$ months (12) & $0.24 \pm 0.01$ & $0.24 \pm 0.01$ & $0.24 \pm 0.01$ & .53 \\
\hline$>2-3$ years $(49)$ & $0.24 \pm 0.02$ & $0.24 \pm 0.02$ & $0.24 \pm 0.02$ & .10 \\
\hline$>3-4$ years $(36)$ & $0.25 \pm 0.02$ & $0.24 \pm 0.02$ & $0.25 \pm 0.03$ & .46 \\
\hline$>4-5$ years (42) & $0.25 \pm 0.03$ & $0.24 \pm 0.02$ & $0.25 \pm 0.03$ & .45 \\
\hline$>5-6$ years (41) & $0.25 \pm 0.02$ & $0.25 \pm 0.02$ & $0.25 \pm 0.03$ & .96 \\
\hline$>6-7$ years (36) & $0.26 \pm 0.02$ & $0.26 \pm 0.03$ & $0.26 \pm 0.02$ & .48 \\
\hline$>7-8$ years (29) & $0.26 \pm 0.03$ & $0.25 \pm 0.03$ & $0.26 \pm 0.03$ & .20 \\
\hline$>8-9$ years $(26)$ & $0.25 \pm 0.02$ & $0.26 \pm 0.02$ & $0.24 \pm 0.02$ & .10 \\
\hline$>9-10$ years $(30)$ & $0.25 \pm 0.02$ & $0.26 \pm 0.02$ & $0.24 \pm 0.02$ & .02 \\
\hline >10-11 years (31) & $0.25 \pm 0.02$ & $0.25 \pm 0.02$ & $0.26 \pm 0.01$ & .36 \\
\hline$>11-12$ years (33) & $0.25 \pm 0.02$ & $0.25 \pm 0.02$ & $0.25 \pm 0.01$ & .49 \\
\hline$>12-13$ years (32) & $0.26 \pm 0.03$ & $0.26 \pm 0.03$ & $0.25 \pm 0.03$ & .72 \\
\hline$>13-14$ years (42) & $0.26 \pm 0.03$ & $0.25 \pm 0.03$ & $0.26 \pm 0.03$ & .55 \\
\hline$>14-15$ years (43) & $0.25 \pm 0.03$ & $0.26 \pm 0.03$ & $0.25 \pm 0.02$ & .99 \\
\hline$>15-16$ years $(69)$ & $0.25 \pm 0.02$ & $0.26 \pm 0.03$ & $0.25 \pm 0.02$ & .29 \\
\hline$>16-17$ years (71) & $0.26 \pm 0.02$ & $0.26 \pm 0.02$ & $0.25 \pm 0.03$ & .58 \\
\hline$>17-18$ years (57) & $0.25 \pm 0.02$ & $0.25 \pm 0.02$ & $0.25 \pm 0.03$ & .43 \\
\hline$>18-19$ years $(46)$ & $0.25 \pm 0.02$ & $0.26 \pm 0.02$ & $0.24 \pm 0.02$ & .07 \\
\hline
\end{tabular}

IO average distance was longer. The findings were not surprising because facial parameters differ among difference ethnicities. $^{1,21,22}$ Our facial parameters were in the line with a recent report from Thailand. ${ }^{20}$

Similar to previous literature, there were no significant differences in our measured parameters between males and females from birth until the early teenage years. ${ }^{23,24}$ However, we noticed differences in our measured parameters between the sexes at ages $\geq 15$ years. A previous study conducted in Thailand by using direct anthropometric measurements also found significant differences between the sexes in their binocular width, which was concordant with our bony LO distance in the adolescent age group. ${ }^{22}$ Another study, from Malaysia, that used 3D facial imaging and anthropometric techniques also found some differences in LO and IC distances between the sexes in late adolescence. ${ }^{25}$ This is not surprising because studies documented that, unlike males, facial growth is usually completed by the age of 14-15 years among females. $^{26,27}$

Our study has some limitations with regard to using samples from a single referral center in northern Thailand and of using a hospitalbased sample. However, our results were in line with the recent study conducted in Bangkok, which indicated that their sample was representative of the normal Thai population. $^{20}$ There were limited longitudinal data because most of the scans used were of unique individuals rather than repeated followup. There is literature that indicates that the cross-sectional design is likely to underestimate growth rates but is useful for determining cutoff normative values because they are more likely to be representative of the healthy population. ${ }^{20,28}$ The strength of our study is the large number of scans, which allowed

Compared with a study conducted in the United States that examined orbital measurements of healthy infants and children, ${ }^{12}$ our average soft-tissue IC distances were slightly lower, whereas, the average bony LO distances were of similar values and our bony more-detailed age- and sex-specific normative values not previously published in an Asian population.

Based on the strengths of our study, our findings have several clinical implications. Establishing normative values is important 
Bony interorbital distance (IO) to body lateral orbital distance (LO) ratio

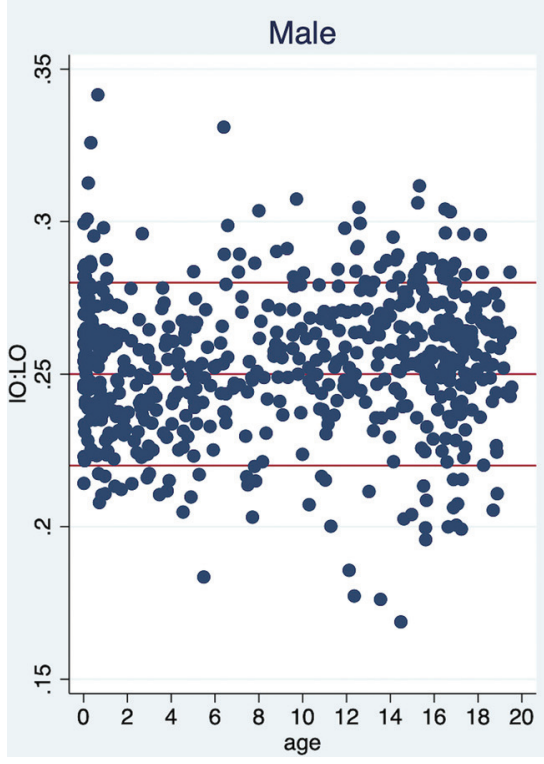

Female

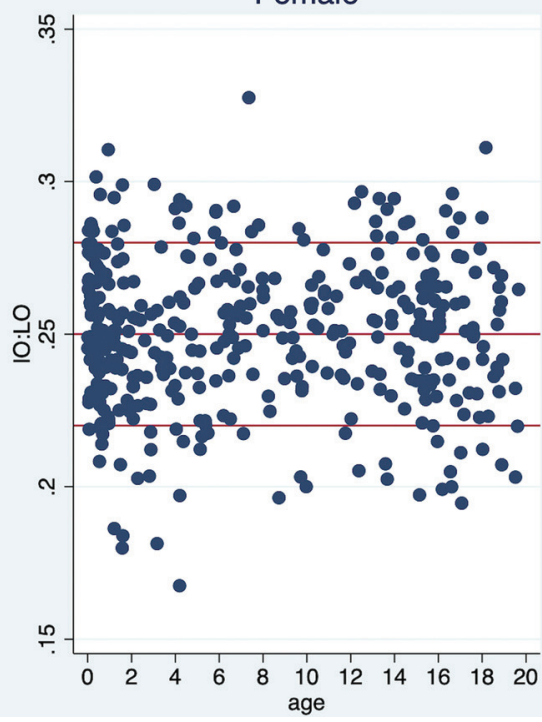

FIG 3. The ratio of the interorbital (IO) to bony lateral orbital (LO) distances by age and sex.

3. Richards CG. Frontoethmoidal meningoencephalocele: a common and severe congenital abnormality in South East Asia. Arch Dis Child 1992;67:717-19 CrossRef Medline

4. Dumrongpisutikul N, Triampo A, Janthanimi $\mathrm{P}$, et al. Incidence of associated brain and ophthalmic anomalies in frontoethmoidal encephalomeningocele evaluated by multidetector computed tomography facial bone imaging. J Craniofac Surg 2017;28:45458 CrossRef Medline

5. Meling TR, Due-Tønnessen BJ, Helseth E, et al. Frontoethmoidal meningoencephaloceles. Tidsskr Nor Laegeforen 2000;120:2250-52 Medline

6. Chowchuen B, Thanapaisal C, Chowchuen P, et al. Frontoethmoidal meningoencephalocele: challenges and the Tawanchai center's long-term integrated management. J Med Assoc Thai 2011;94(Suppl):S129-40 Medline

7. Harris R, Nagarkar P, Amirlak B. Varied definitions of nasolabial angle: searching for consensus among rhinoplasty surgeons and an algorithm for

because a diagnosis of craniofacial abnormality, for example, telecanthus, relies on age- and sex-specific means and SDs. To avoid or reduce the number of unnecessary postoperative CTs, the values of soft-tissue IC can be used for follow-up of patients after craniofacial surgery, such as frontoethmoidal encephalomeningocele correction, craniofacial cleft correction, orbital translocation, and facial bipartition. The understanding of normal growth development also helps identify the timing of surgery of craniofacial anomalies, such as frontonasal dysplasia, hypertelorism, and craniofacial cleft because correction of the orbital complex or glabella region should be performed when the bones are nearly fully grown. Results of our study suggest that the facial parameters are almost fully developed around the age of 8 years in this population. The finding that the IO:LO ratio is relatively constant, at 0.25 , across ages and sexes helps inform surgeons on the aesthetic or cosmetic facial ratio for pre-, intra-, and postoperative evaluations.

\section{CONCLUSIONS}

This study provides detailed age-and sex-specific normative data of the craniofacial measurement in children and adolescents in Thailand based on CT imaging. These data can be used for evaluating individual patients with craniofacial abnormalities as well as determining the treatment in Thai and Asian populations where craniofacial abnormalities, for example, frontoethmoidal encephalomeningocele, are common.

\section{REFERENCES}

1. Farkas LG, Katic MJ, Forrest CR. Comparison of craniofacial measurements of young adult African-American and North American white males and females. Ann Plast Surg 2007;59:692-98 CrossRef Medline

2. Patil SB, Kale SM, Math M, et al. Anthropometry of the eyelid and palpebral fissure in an Indian population. Aesthet Surg $J$ 2011;31:290-94 CrossRef Medline selecting the ideal method. Plast Reconstr Surg Glob Open 2016;4:e752 CrossRef Medline

8. Le TT, Farkas LG, Ngim RCK, et al. Proportionality in Asian and North American Caucasian faces using neoclassical facial canons as criteria. Aesthetic Plast Surg 2002;26:64-69 CrossRef Medline

9. Farkas LG, Tompson BD, Katic MJ, et al. Differences between direct (anthropometric) and indirect (cephalometric) measurements of the skull. J Craniofac Surg 2002;13:105-10; discussion 109-10 CrossRef Medline

10. Park DH, Choi WS, Yoon SH, et al. Anthropometry of Asian eyelids by age. Plast Reconstr Surg 2008;121:1405-13 CrossRef Medline

11. Laestadius ND, Aase JM, Smith DW. Normal inner canthal and outer orbital dimensions. J Pediatr 1969;74:465-68 CrossRef Medline

12. Pool GM, Didier RA, Bardo D, et al. Computed tomography-generated anthropometric measurements of orbital relationships in normal infants and children. J Neurosurg Pediatr 2016;18:201-06 CrossRef Medline

13. Farkas LG, Hreczko TM, Katic MJ, et al. Proportion indices in the craniofacial regions of 284 healthy North American white children between 1 and 5 years of age. J Craniofac Surg 2003;14:13-28 CrossRef Medline

14. Matteson SR, Bechtold W, Phillips C, et al. A method for threedimensional image reformation for quantitative cephalometric analysis. J Oral Maxillofac Surg 1989;47:1053-61 CrossRef Medline

15. Christiansen EL, Thompson JR, Kopp S. Intra- and inter-observer variability and accuracy in the determination of linear and angular measurements in computed tomography: an in vitro and in situ study of human mandibles. Acta Odontol Scand 1986;44:221-29 CrossRef Medline

16. Waitzman AA, Posnick JC, Armstrong DC, et al. Craniofacial skeletal measurements based on computed tomography: part I. Accuracy and reproducibility. Cleft Palate Craniofac J 1992;29:11217 CrossRef Medline

17. Farkas LG. Accuracy of anthropometric measurements: past, present, and future. Cleft Palate Craniofac J 1996;33:10-18; discussion 19-22 CrossRef Medline

18. Richtsmeier JT, Paik CH, Elfert PC, et al. Precision, repeatability, and validation of the localization of cranial landmarks using 
computed tomography scans. Cleft Palate Craniofac J 1995;32:21727 CrossRef Medline

19. Gupta V, Prabhakar A, Yadav M, et al. Computed tomography imaging-based normative orbital measurement in Indian population. Indian J Ophthalmol 2019;67:659-63 CrossRef Medline

20. Chatdokmaiprai $C$, Kiranantawat K, Lertsithichai $P$, et al. Normative data of the interorbital distance in Thai population. J Craniofac Surg 2018;29:1939-44 CrossRef Medline

21. Prendergast PM. Facial proportions. In: Erian A, Shiffman MA, eds. Advanced Surgical Facial Rejuvenation. New York: Springer-Verlag Berlin Heidelberg; 2012:15-22

22. Farkas LG, Katic MJ, Forrest CR, et al. International anthropometric study of facial morphology in various ethnic groups/races. $J$ Craniofac Surg 2005;16:615-46 CrossRef Medline
23. Freihofer HP. Inner intercanthal and interorbital distances. J Maxillofac Surg 1980;8:324-26 CrossRef Medline

24. Méhes K, Kitzvéger E. Inner canthal and intermamillary indices in the newborn infant. J Pediatr 1974;85:90-92 CrossRef Medline

25. Othman SA, Majawit LP, Wan Hassan WN, et al. Anthropometric study of three-dimensional facial morphology in Malay adults. PLoS One 2016;11:e0164180 CrossRef Medline

26. Palmert MR, Dunkel L. Clinical practice. Delayed puberty. $N$ Engl $J$ Med 2012;366:443-53 CrossRef Medline

27. Ferrario VF, Sforza C, Poggio CE, et al. Craniofacial growth: a three-dimensional soft-tissue study from 6 years to adulthood. J Craniofac Genet Dev Biol 1998;18:138-49 Medline

28. Preece MA. Standardization of growth. Acta Paediatr Scand Suppl 1989;78:57-64; discussion 81-83 CrossRef Medline 